\title{
Affective Management and its Effects on Management Performance
}

\section{Waratta Authayarat*, Hiroyuki Umemuro**}

\begin{abstract}
Affective management is a new concept which suggests that top managers should take stakeholders' affective experiences into account when making their management decisions. To show that this concept could contribute to the improvement of management performance in organizations, this study investigated the correlations between the affectiveness of top management and management performance indices. Our questionnaire based on the Affective Management Scorecard was employed to assess top managers' recognition of the importance, as well as the actual practices of affective management. Top managers from 43 Thai organizations participated in the study. A correlation analysis was conducted to observe whether affective management indices would correlate with management performance indices, such as return on equity, return on assets, price to earnings ratio, and price to book value ratio. The findings showed that the results for organizations practicing affective management were positively correlated with their management performance in both profitability and good perceptions by investors.
\end{abstract}

Keywords: affective management, stakeholder, management, affect, emotion, feeling.

\section{Introduction}

In principle and in practice, management decision-making has traditionally been based on objective measurements such as costs, sales, benefits, and efficiency. Recently, a new concept emerged suggesting that those objective measurements might not be a sufficient basis for decision-making, and that decisions focusing on the affective experiences of all stakeholders, as well as the objective measurements, would be more appropriate (Authayarat, Umemuro, Murata, and Jiamsanguanwong, 2011; Strong, Ringer, and Taylor, 2001; Umemuro, 2009, 2011). Affective management is defined

\footnotetext{
* Waratta Authayarat, Department of Industrial Engineering and Management, Tokyo Institute of Technology, Tokyo 152-8550, authayarat.w.aa@m.titech.ac.jp.

** Associate Professor Hiroyuki Umemuro, Department of Industrial Engineering and Management, Tokyo Institute of Technology, Tokyo 152-8550, umemuro.h.aa@m.titech.ac.jp.
} 
as management that takes stakeholders' affective experiences into consideration in management decisions (Umemuro, 2011). The capability of top management to consider the affective influence on stakeholders (hereafter affectiveness) is an important measure to evaluate management quality or overall organizational quality (Umemuro, 2011).

Conventional management has emphasized efficiency, including reducing costs, but affective management emphasizes the stakeholder's affective experiences. For example, a product might be designed especially for a customer, deliberately including superior building design, quality materials, and skilled finishes, and this may result in additional costs (Umemuro, 2009). Thus, when top management considers affective experiences of stakeholders, the idea may conflict with conventional management theories based on rational and objective measurements (Authayarat et al., 2011; Umemuro, 2009). To claim that affective management actually leads to better performance, the relationship between the extent to which management considers stakeholders' affective experiences in their decisions and actual organizational performance needs to be established.

To show the effectiveness of affective management, it is crucial to have the means to measure it. Two approaches for evaluating affectiveness are possible. One is to perform an evaluation based on publically available information, such as financial reports or corporate social responsibility (CSR) reports. However, as public information is authored by the organizations themselves, the information may be biased. Another way is to base the evaluation on the direct assessment of top management, through such means as interviews or questionnaires. Although this approach may be costly, the results would be highly accurate and trustworthy if systematic measurement methods were employed. Authayarat et al. (2011) proposed the Affective Management Scorecard to assess and quantify the affectiveness of an organization. This study employed this scorecard as a measurement of affectiveness of organizations, and compared the results with conventional management performance.

The purpose of this study was to investigate the relationship between the affectiveness of organizations' top management and their management performances. A questionnaire-based investigation was conducted with top management from 43 Thai organizations. The Affective Management Scorecard was employed to assess the affectiveness of the respondents. Overall scores of affectiveness were calculated and an analysis performed by stakeholder categories. These scores were compared with management performance indices for profitability and market valuations.

\section{Related works and hypotheses}

\section{Affective management}

In psychology, the term affect has long been used to represent a person's general response, including emotion, mood, and feeling. In this study, affective is defined as 
being capable of involving a person's mind or as being capable of provoking deliberate responses in a person's mind (Umemuro, 2009).

Affective management can be defined as "management of an organization that takes into consideration the potential influences of its decision-making on its stakeholders' affects or affective experiences" (Umemuro, 2011, p. 514). Affective management should recognize what might potentially influence people's affects and evaluate the possible impacts. This concept promotes the idea that top management should make decisions considering not only conventional quantitative indices but also the effects of decisions upon the affective experiences of stakeholders (Authayarat et al., 2011; Umemuro, 2009, 2011).

Although the concept of affective management may have only recently emerged in the field of management, successful managers have long understood the influence of affect in their decisions and behaviors. However, those managers have practiced this concept implicitly or subconsciously, as it has not been explicitly identified and still remains in the shadows of rational decision-making (Umemuro, 2009). Amsa (1991) reports the urgent need for "a mature ideational construct and conceptual framework for understanding and improving the affective world of management students or the embryo managers" (p. M130). This desire is to prepare tomorrow's managers to relate to the real world - to its emotions, passions, dispositions, motives, moral and aesthetic sensibilities, capacity for feeling, concern, attachment or detachment, sympathy, and appreciation (Amsa, 1991). To further understand, endorse, and promote this concept, we need evidence that it also promotes good management performance.

\section{Stakeholders of affective management}

A stakeholder is defined as any individual or group who affects or is affected by the organization and its processes, activities, and functioning (Carroll and Näsi, 1997). Frequently, companies only focus on the specific stakeholder targets stated in their company mission statement or annual report (Campbell, Shrives and BohmbachSaager, 2001). However, the affective management concept requires that not only customers, but also employees, the local community, and society in general should be included. Top management should pay attention to the affects of these stakeholders.

\section{Customers as stakeholders}

Management is concerned with many aspects of how the company can best serve its customers (Bahn, Lee, Nam, and Yun, 2009; Larson, 2009; Locke 1996; Millard, 2006; Parasuraman, Zeihaml, and Berry, 1988). It is common for consumer-oriented product development to be the focus because there is competition between goods in the market. Customers tend to buy attractive products or services that affect their feelings (Nagamachi, 2008). Tang and Umemuro (2012) extracted the affective factors that can elicit a person's emotions in products. Vendors of products and services should not only be concerned with the functionality and usability of the products, but should 
also find out how their products can evoke customers' emotions such as feelings of enjoyment or pride (Norman, 2004).

The customer's affective experience, through word-of-mouth, ownership, and by providing suggestions and complaints, is the first stage in developing loyalty and commitment (Millard, 2006). Once customers perceive high quality service or have positive affective experiences with products or services, they become loyal customers (Devaraj, Matta, and Conlon, 2001; Lewis and Soureli, 2006). Retaining loyal customers who positively and intentionally spread recommendations by word-of-mouth makes good business sense (Millard, 2006) and is sustainable over a long period (Locke, 1996; Reinartz and Kumar, 2003). Significantly, perceived service quality improves the company's sales performance (Babakus, Bienstock, and Scotter, 2004). From the investors' perspective, Nayyar (1995) reported that improvements in customer service are positively valued and decreases in customer service are negatively valued by the stock market.

The nature of businesses can vary depending on the target customers, being either personal customers or business customers. Business-to-customer (B2C) and businessto-business (B2B) companies are different. B2C companies may focus more on the importance of customers' affective experiences to increase their share and survive in the market with the general public, while B2B companies rely on more specific and a limited number of business customers. Thus, the concern from top management toward customers or business customers may be unequal. This idea leads to the first and second hypotheses.

H1: Management that takes care of and considers the importance of customers' affects tends to have higher management performance.

$\mathrm{H} 2$. The correlations between affectiveness and management performance of $\mathrm{B} 2 \mathrm{C}$ are higher than for B2B.

\section{Employees as stakeholders}

Employees are one of the most important mechanisms that drive and maintain an organization. The consequences of employees' positive affective experiences have received much attention and have been widely acknowledged (Fisher, 2003; Lyubomirsky, King, and Diener, 2005; Staw and Barsad, 1993; Zelenski, Murphy, and Jenkins, 2008; see Fisher, 2010 for review). The claim by Zelenski et al. (2008) that employees' positive affects contribute to productivity is similar to other studies (Fisher, 2003; Lyubomirsky et al., 2005; Staw and Barsade, 1993). Previous studies have suggested that employees who experience more positive affects are more productive, and thus people are at their most productive when experiencing positive moods (Harter, Schmidt, and Hayes, 2002).

Positive affects among employees also increase task persistence and performance, resulting in higher motivation levels (Erez and Isen, 2002; llies and Judge, 2002; George and Brief, 1996). Positive affect is associated with the process of motivating employees (Fisher, 2010, Fredrickson, 2003). Positive affective experience may result in job 
satisfaction and employee engagement with the organization, which are also likely to be associated with employee effectiveness and good job performance (Harrison, Newman, and Roth, 2006).

Engagement of employees is also related to their happiness (Stair and Galpin, 2010). Strong engagement improves effort and employee performance (Hodges and Asplund, 2010). Engagement is a concept that goes beyond "satisfaction" or "motivation" (Stairs and Galpin, 2010). It involves positive affective experiences regarding work, and as a result employees are willing to go the extra mile to complete jobs to the best of their abilities (Truss, Edwards, Wisdom, Croll and Burnett, 2006). Earlier studies have shown that organizations with strong employee engagement achieve higher profits (Harter et al., 2002, 2010). Affective involvement of employees as stakeholders leads to the following hypothesis:

H3: Management that takes care of and considers the importance of employees' affects tends to achieve higher management performance.

\section{Local community and society as stakeholders}

The local community stakeholder refers to a community nearby to an organization, and one that interacts with the organization; society stakeholder refers to people in the general public (Authayarat et al., 2011). Affective management should also take care of people outside the organization, in terms of both emotional and well-being issues.

Organizations may reinforce the positive affective experiences of the community through various activities. These may include taking good care of the community environment, providing financial support to community activities such as sports or education, and by providing special experiences such as inviting local people to view the production facilities. These generate the community's positive affective experiences towards the organization and increase the engagement of local customers. As a result, they promote community sustainability and, in turn, bring reputational profits to the organization and increase the long-term market valuation (Bird, Hall, and Momentè, 2007).

Providing affective experiences for society members is a significant challenge for affective management. Organizations are considered as social actors embedded in society and responsible for social activities by providing products and services to social members as they are needed (Branco and Rodrigues, 2006). Society is protected by CSR activities that are designed to prevent or repair the negative impact of the business or operations on society (Branco and Rodrigues, 2006), and, on a larger scale, improve quality of life (Holme and Watts, 2000, cited in Branco and Rodrigues, 2006). The benefits from such activities may attract interested people in society who are current or potential customers and, thus, may become a potential trend for sustaining organizational growth (Authayarat et al., 2011) and financial performance (Branco and Rodrigues, 2006; McWilliam and Siegel, 2000). The business benefits of CSR can also include economic sustainability through developing and enhancing relationships 
with customers through products or services, increasing customer and shareholder retention, and developing the company's networks. As a result, organizations that apply CSR develop a unique selling point that sets them apart from competitors (Bird et al., 2007; Whitehouse, 2006); for example, by reducing energy costs (Bird et al., 2007). CSR is a way of achieving long-term results and maintaining business continuity (Branco and Rodrigues, 2006).

The size of the organization may influence the practice of affective management. In the case of CSR, small companies tend to be less familiar with the concept and might find it difficult to put it into practice (Broeck, 2009). Affective management might be in a similar situation. Large organizations with many employees may be more concerned with affective management than small ones. The notion of community as stakeholders leads to the fourth, fifth, and sixth hypotheses.

H4: Management that considers and responds to the importance of the local community's affects tends to have higher management performance.

H5: Management that considers and responds to the importance of society's affects tends to have higher management performance.

H6: The size of an organization affects how it recognizes and practices the affective management concept.

\section{Method}

\section{Participants}

Participants were top managers of organizations listed on the Stock Exchange of Thailand. A questionnaire was sent to 380 businesses in six sectors: service (22.1\%), consumer products $(10.3 \%)$, property and construction (28.7\%), agricultural and food $(10.5 \%)$, resources $(7.1 \%)$, and industrial products $(21.3 \%)$.

\section{Procedure}

This investigation was conducted between early March and May 2011. Each participant received a questionnaire as well as a brief outline explaining the concept of affective management and the importance of top managers taking part in this research. The questionnaire investigated the extent to which participants recognized the importance of considering stakeholders' affects when making management decisions, and the extent to which they actually put affective management into practice. Participants were asked to provide demographic data and profiles of their organizations. Participants were also asked to complete the questionnaire in their own time and return it to the investigator by post.

\section{Measurement}

The Affective Management Scorecard developed by Authayarat et al. (2011) was used to measure affectiveness in this study. This scorecard consists of 15 dimensions, such as a company's products or services, company's brand, and company's philosophy and 
corporate identity. These dimensions corresponded to issues that the top managers would have to make decisions about in the course of their jobs (see Table 1 for overall dimensions and relations with each stakeholder). For each dimension, there were three question types. The first type asked whether the respondent made decisions on issues in each of the 15 dimensions (e.g., "Do management boards make decisions about the company's philosophy and corporate identity?"). The second type asked how much the top manager believed that each of the 15 dimensions was important to each of the stakeholders' affects (e.g., "How much do management boards believe that the company's philosophy and corporate identity are important for employee's affects?"). The final question type asked to what extent top managers actually considered stakeholders' affects when they made decisions regarding the 15 dimensions (e.g., "To what extent do management boards consider employee's affects when making decisions about the company's philosophy and corporate identity?"). For the second and third type of questions, participants were asked to respond using a five-point Likert scale ( $1=$ not at all, $5=$ very much). In the process of developing a scorecard and improving its reliability, the content was examined by specialists from various fields of industry and tested with pilot samples that were not a target group. Thus, the scorecard was considered to have valid items and high reliability (Cronbach's alpha = 0.96) (Authayarat et al., 2011).

Based on the responses, two types of affectiveness scores were calculated: a winning score and an average score. Table 2 illustrates how the winning score was calculated. Winning score reflects how top managers recognize both the importance of stakeholders' affects (Im or importance score) and actually consider them when making decisions in practice ( $\mathrm{Pr}$ or practice score). Likert scale responses were coded into levels (scores of 4 or 5 coded as high, 3 as medium, and 1 or 2 as low) of affectiveness for each decision-making dimension and each stakeholder. The winning scores reflected combinations of recognition of importance and actual practice and ranged between -2 and +2 . For example, if a respondent scored the "importance" of a question item as "high" (4 or 5) and the actual "practice" of it as "medium" (3), the winning score for the item will be +1 . In the same way, if the "importance" was scored as "high" and the "practice" was scored as "low", the score will be 0. Positive winning scores represented top managers who both recognized the importance and actually considered the stakeholders' affects in their decision-making. Conversely, negative scores reflected the managers who neither recognized the importance of stakeholders' affects nor practiced affectiveness. The average of the winning scores across all dimensions and all stakeholders was defined as the affectiveness winning score. 
Table 1. Affective Management Scorecard dimensions and relations with each stakeholder

\begin{tabular}{|c|c|c|c|c|c|c|c|c|c|}
\hline \multirow{3}{*}{ No. } & \multirow{3}{*}{ Dimension } & \multicolumn{8}{|c|}{ Stakeholder } \\
\hline & & \multicolumn{2}{|c|}{ Customer } & \multicolumn{2}{|c|}{ Employee } & \multicolumn{2}{|c|}{$\begin{array}{l}\text { Local } \\
\text { community }\end{array}$} & \multicolumn{2}{|c|}{ Society } \\
\hline & & Im & $\operatorname{Pr}$ & Im & $\operatorname{Pr}$ & Im & $\operatorname{Pr}$ & Im & $\operatorname{Pr}$ \\
\hline 1 & Company's product/service & 0 & 0 & 0 & 0 & 0 & 0 & 0 & $\mathrm{O}$ \\
\hline 2 & $\begin{array}{l}\text { Company's philosophy and corporate } \\
\text { identity }\end{array}$ & 0 & 0 & $\mathrm{O}$ & 0 & 0 & 0 & 0 & 0 \\
\hline 3 & Company's brand & $\mathrm{O}$ & $\mathrm{O}$ & $\mathrm{O}$ & $\mathrm{O}$ & 0 & $\mathrm{O}$ & $\mathrm{O}$ & $\mathrm{O}$ \\
\hline 4 & $\begin{array}{l}\text { Business strategy or plan, project } \\
\text { management, business process, } \\
\text { performance of company's activity }\end{array}$ & $\mathrm{O}$ & 0 & $\mathrm{O}$ & 0 & 0 & 0 & $\mathrm{O}$ & $\mathrm{O}$ \\
\hline 5 & Organization's structure & $\mathrm{O}$ & $\mathrm{O}$ & 0 & 0 & & & & \\
\hline 6 & Company's investment & $\mathrm{O}$ & 0 & $\mathrm{O}$ & 0 & & & $\mathrm{O}$ & $\mathrm{O}$ \\
\hline 7 & Price of product or service & $\mathrm{O}$ & 0 & & & 0 & 0 & $\mathrm{O}$ & $\mathrm{O}$ \\
\hline 8 & Human resource & & & 0 & 0 & 0 & 0 & & \\
\hline 9 & $\begin{array}{l}\text { Advertisement and customer's community } \\
\text { or communication }\end{array}$ & $\mathrm{O}$ & $\mathrm{O}$ & $\mathrm{O}$ & $\mathrm{O}$ & 0 & 0 & $\mathrm{O}$ & $\mathrm{O}$ \\
\hline 10 & $\begin{array}{l}\text { Product patent and industrial standard (e.g., } \\
\text { ISO, JIS) }\end{array}$ & $\mathrm{O}$ & $\mathrm{O}$ & O & 0 & & & 0 & 0 \\
\hline 11 & Office equipment & & & $\mathrm{O}$ & 0 & & & & \\
\hline 12 & $\begin{array}{l}\text { Atmosphere at workplace and team } \\
\text { management }\end{array}$ & & & $\mathrm{O}$ & 0 & & & & \\
\hline 13 & $\begin{array}{l}\text { Payment and welfare system (e.g., job } \\
\text { training, education, health care system) }\end{array}$ & & & $\mathrm{O}$ & 0 & & & & \\
\hline 14 & Location and construction design & $\mathrm{O}$ & 0 & $\mathrm{O}$ & 0 & 0 & 0 & $\mathrm{O}$ & $\mathrm{O}$ \\
\hline 15 & CSR activity & $\mathrm{O}$ & $\mathrm{O}$ & $\mathrm{O}$ & 0 & 0 & $\mathrm{O}$ & $\mathrm{O}$ & $\mathrm{O}$ \\
\hline
\end{tabular}

Table 2. Winning Score System

\begin{tabular}{lrccc}
\hline & & High & $\begin{array}{c}\text { Practice } \\
\text { Medium }\end{array}$ & Low \\
\hline \multirow{3}{*}{ Importance } & High & +2 & +1 & 0 \\
& Medium & +1 & 0 & -1 \\
& Low & 0 & -1 & -2 \\
\hline
\end{tabular}

The second score type, average score, was a simple average of responses on the Likert scales across all dimensions and stakeholders. For ease of understanding, the average scores were converted linearly as a range of 0-100. Affectiveness average scores represented the overall tendency of how top managers recognized the importance of and actually considered the stakeholders' affects when making decisions. Average scores were also calculated for each stakeholder, calculating averages across 15 dimensions and across recognition and practice, and further 
converted to a range of $0-100$. These average scores by stakeholders are referred to as stakeholder sub-scores (e.g., customer sub-score, employee sub-score) hereafter.

Return on assets (ROA), return on equity (ROE), price to earnings ratio (PER), price to book-value ratio (PBR), and profit after tax as of the end of the fiscal year 2010 were used as measurements of management performance. These data for the participants' organizations were sourced from the Stock Exchange of Thailand (www.set.or.th/en/ index.html), which has had sufficient liquidity and efficiency in previous years, and thus stock prices used in this research can be considered as efficiently or reasonably priced (www.set.or.th/en/market/market_statistics.html\#annual). In addition, log values of number of employees as of the end of the fiscal year 2010 were used as an index of the size of the organization.

\section{Results}

Of the 380 questionnaires sent to top managers, 43 were completed and returned. Table 3 shows the demographic data of the participants. The majority of respondents were male (79.5\%). Most of the participants were aged between 41 and 60 years old and had gained a master's degree.

Table 4 shows the number of participants by industry sector. Overall the return rate was $11.3 \%$, while return rates of the industry types were $7.1 \%$ for service, $10.3 \%$ for consumer products, $11.0 \%$ for property and construction, $12.5 \%$ for agriculture and food products, $18.5 \%$ for resources, and $13.6 \%$ for industrial products. The proportional returns of each industry type were essentially in the same, approximately $10 \%$, thus the respondents can be said to represent samples of all the industries. Of the 43 respondents, 23 were engaged in B2B businesses, 15 in B2C businesses, and 5 were engaged in both B2B and B2C businesses as shown in Table 5 .

\section{Correlations between affectiveness and management performance}

A series of correlation analyses was conducted to investigate the correlation between the affectiveness scores and management performance of the organizations. Although the number of samples in this study is rather limited, it is still possible to argue the relationships between affectiveness scores and performance indices when significant correlations are available. Thus, correlation analysis was adopted in this study.

Table 6 shows the Pearson's correlation coefficients between affectiveness scores (affectiveness winning scores, average scores, and stakeholders sub-scores), ROA, and ROE. Table 6 shows that there were no significant correlations between overall winning score or average score and financial performances (ROA and ROE). However, employee sub-score was moderately correlated with ROA $(r=0.30, p<0.10)$. This result means that companies with high employee sub-scores tended to have high ROA. Thus, these findings suggest that organizations that care about employees' affect are more likely to yield stronger financial performances. 
Table 3. Demographic data of respondents

\begin{tabular}{clcc}
\hline & & Number of responses $^{\text {a }}$ & Percentage \\
\hline \multirow{4}{*}{ Gender } & Male & 31 & 79.5 \\
& Female & 8 & 20.5 \\
& Total & 39 & 100.0 \\
\hline \multirow{5}{*}{ Age } & $<40$ years old & 7 & 20.0 \\
& $41-50$ years old & 13 & 33.3 \\
& 51-60 years old & 14 & 35.9 \\
& $>60$ years old & 5 & 12.8 \\
& Total & 39 & 100.0 \\
\hline \multirow{5}{*}{ Education } & 11 & 28.2 \\
& Bachelor's degree & 25 & 64.1 \\
& Master's degree & 3 & 7.7 \\
& Doctor's degree & 39 & 100.0 \\
& Total &
\end{tabular}

Note. ${ }^{\text {a }}$ The total number in each subcategory may not equal 43 because of missing data.

Table 4. Respondent population by industry sector and response rates for questionnaires

\begin{tabular}{lcc}
\hline \multicolumn{1}{c}{ Types of industry } & Sent $(\mathbf{n}, \mathbf{( \% )})$ & Returned $(\mathbf{n}, \mathbf{( \% )})$ \\
\hline Service & $84(22.1)$ & $6(14.0)$ \\
Consumer products & $39(10.3)$ & $4(9.3)$ \\
Property and construction & $109(28.7)$ & $12(27.9)$ \\
Agro and food products & $40(10.5)$ & $5(11.6)$ \\
Resource & $27(7.1)$ & $5(11.6)$ \\
Industrial products & $81(21.3)$ & $11(25.6)$ \\
\hline Total & $380(100.0)$ & $43(100.0)$
\end{tabular}

Table 5. Organization data according to each respondent

\begin{tabular}{|c|c|c|c|c|c|}
\hline Industry & Respondent & Sector & $\begin{array}{c}\text { Business } \\
\text { type }\end{array}$ & $\begin{array}{c}\text { No. of } \\
\text { Employees }\end{array}$ & $\begin{array}{c}\text { Company } \\
\text { age }\end{array}$ \\
\hline \multirow{6}{*}{ 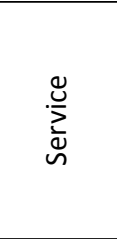 } & R1 & Transportation \& logistics & $\mathrm{B} 2 \mathrm{~B}, \mathrm{~B} 2 \mathrm{C}$ & 4570 & 7 \\
\hline & R2 & Transportation \& logistics & B2B & 296 & 15 \\
\hline & R3 & Health care services & $\mathrm{B} 2 \mathrm{C}$ & $\mathrm{N} / \mathrm{A}$ & 20 \\
\hline & R4 & Tourism and leisure & $\mathrm{B} 2 \mathrm{C}$ & 11307 & 21 \\
\hline & R5 & Tourism and leisure & B2B & 73 & 6 \\
\hline & R6 & Media and publishing & B2B & 1402 & 7 \\
\hline \multirow{4}{*}{ 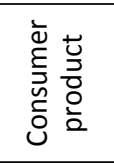 } & R7 & Fashion & $\mathrm{B} 2 \mathrm{C}$ & 487 & 34 \\
\hline & R8 & Fashion & B2B & 11312 & 23 \\
\hline & R9 & Personal and pharmaceutical products & $\mathrm{B} 2 \mathrm{~B}$ & 1680 & 23 \\
\hline & R10 & Personal and pharmaceutical products & $\mathrm{B} 2 \mathrm{~B}, \mathrm{~B} 2 \mathrm{C}$ & 1539 & 5 \\
\hline \multirow{7}{*}{ 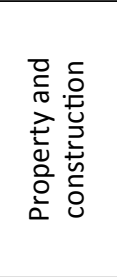 } & R11 & Property development & $\mathrm{B} 2 \mathrm{C}$ & $\mathrm{N} / \mathrm{A}$ & 5 \\
\hline & R12 & Property development & $\mathrm{B} 2 \mathrm{C}$ & 2823 & 16 \\
\hline & R13 & Property development & $\mathrm{B} 2 \mathrm{C}$ & $\mathrm{N} / \mathrm{A}$ & 21 \\
\hline & R14 & Property development & B2B & 1089 & 7 \\
\hline & R15 & Property development & $\mathrm{B} 2 \mathrm{C}$ & 142 & 2 \\
\hline & R16 & Property development & $\mathrm{B} 2 \mathrm{C}$ & 486 & 18 \\
\hline & R17 & Property development & B2B & 188 & 9 \\
\hline
\end{tabular}




\begin{tabular}{|c|c|c|c|c|c|}
\hline Industry & Respondent & Sector & $\begin{array}{c}\text { Business } \\
\text { type }\end{array}$ & $\begin{array}{c}\text { No. of } \\
\text { Employees }\end{array}$ & $\begin{array}{c}\text { Company } \\
\text { age }\end{array}$ \\
\hline \multirow{5}{*}{ 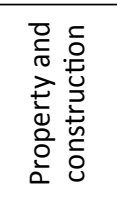 } & R18 & Property development & B2B & N/A & 6 \\
\hline & R19 & Property development & B2B & $\mathrm{N} / \mathrm{A}$ & 2 \\
\hline & $\mathrm{R} 20$ & Property development & B2B & $N / A$ & 2 \\
\hline & $\mathrm{R} 21$ & Construction materials & $\mathrm{B} 2 \mathrm{C}$ & 2471 & 19 \\
\hline & $\mathrm{R} 22$ & Construction materials & $\mathrm{B} 2 \mathrm{~B}, \mathrm{~B} 2 \mathrm{C}$ & 30820 & 36 \\
\hline \multirow{5}{*}{ 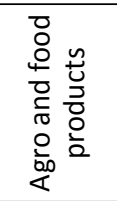 } & $\mathrm{R} 23$ & Food and beverage & $\mathrm{B} 2 \mathrm{C}$ & 65206 & 24 \\
\hline & R24 & Food and beverage & $\mathrm{B} 2 \mathrm{C}$ & 18036 & 23 \\
\hline & R25 & Food and beverage & B2C & 878 & 3 \\
\hline & $\mathrm{R} 26$ & Food and beverage & B2C & 3195 & 33 \\
\hline & $\mathrm{R} 27$ & Agribusiness & B2B & 419 & 17 \\
\hline \multirow{5}{*}{ 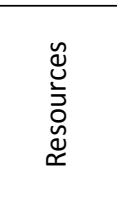 } & $\mathrm{R} 28$ & Energy and utilities & $\mathrm{B} 2 \mathrm{~B}, \mathrm{~B} 2 \mathrm{C}$ & 994 & 17 \\
\hline & $\mathrm{R} 29$ & Energy and utilities & B2C & 148 & 14 \\
\hline & R30 & Energy and utilities & $\mathrm{B} 2 \mathrm{C}$ & 441 & 16 \\
\hline & R31 & Energy and utilities & B2B & $\mathrm{N} / \mathrm{A}$ & 2 \\
\hline & R32 & Energy and utilities & B2B & 5199 & 16 \\
\hline \multirow{11}{*}{ 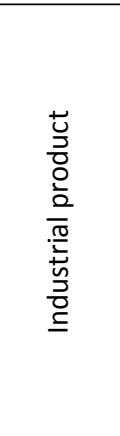 } & R33 & Steel & B2B & 594 & 20 \\
\hline & R34 & Steel & B2B & 260 & 6 \\
\hline & R35 & Steel & B2B & $\mathrm{N} / \mathrm{A}$ & 16 \\
\hline & R36 & Industrial material and machinery & B2B & 578 & 19 \\
\hline & R37 & Industrial material and machinery & B2B & 1822 & 7 \\
\hline & R38 & Industrial material and machinery & B2B & $\mathrm{N} / \mathrm{A}$ & 16 \\
\hline & R39 & Petrochemical and chemical products & B2B & 93 & 6 \\
\hline & $\mathrm{R} 40$ & Petrochemical and chemical products & $\mathrm{B} 2 \mathrm{~B}, \mathrm{~B} 2 \mathrm{C}$ & 202 & 16 \\
\hline & R41 & Petrochemical and chemical products & B2B & 1030 & 27 \\
\hline & $\mathrm{R} 42$ & Automotive & B2B & 830 & 6 \\
\hline & $\mathrm{R} 43$ & Packaging & B2B & 821 & 34 \\
\hline
\end{tabular}

Table 6. Pearson's correlation coefficients between affectiveness scores and management performance (ROA and ROE)

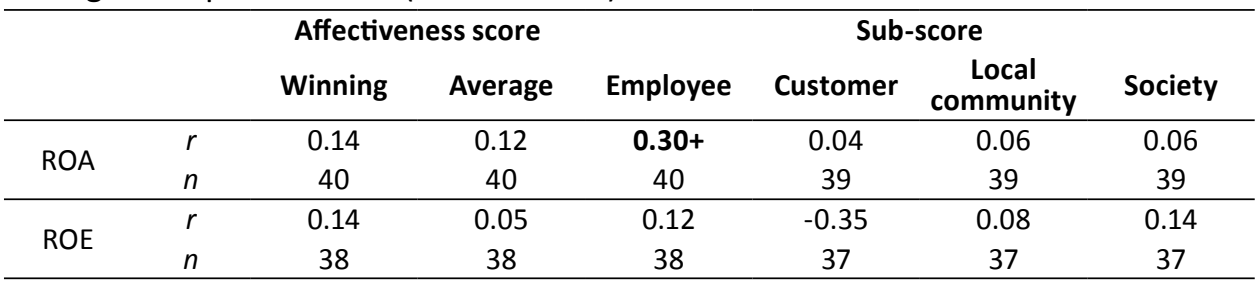

Note. $+p<0.10$.

Table 7 shows Pearson's correlation coefficients between affectiveness scores and PER, PBR, and net profit margin. In Table 7, both winning score and average score were moderately correlated with PER (winning score: $r=0.32, p<0.10$; average score: $r=$ $0.31, p<0.10$ ) and PBR (winning score: $r=0.30, p<0.10$; average score: $r=0.31, p<$ $0.10)$, while they were not correlated with net profit margin.

The employee sub-score was moderately correlated with PBR $(r=0.29, p<0.10)$ and net profit margin $(r=0.28, p<0.10)$. This finding means that the companies with 
high employee sub-scores tended to have higher PBR and net profit margins. Thus, this result suggests that organizations that take employees' affects into account yield better financial performances. This result partially proves the third hypothesis that if affective management focuses on employees' affects, then ROA, PBR, and the net profit margin of the organization will improve.

The customer sub-score was significantly correlated with PER $(r=0.36, p<0.05)$ and PBR $(r=0.38, p<0.05)$. This result shows that companies with high customer sub-scores had higher PER and PBR. This result indicates that organizations that highly value customers' affects yield better performances, and thus supports, in part, the first hypothesis that affective management that prioritizes customers' affects will increase PER and PBR.

The society sub-score was significantly correlated with PBR $(r=0.35, p<0.05)$. This result implies that management that cares about the affect on society results in high PBR, and thus partially supporting the fifth hypothesis. However, there was no support for the fourth hypothesis.

Finally, Table 8 shows the correlations between the affective scores and the size of the organizations. The size of the organization was significantly correlated with the affectiveness scores: winning score $(r=0.40, p<0.05)$, average score $(r=0.42, p<0.01)$, customer subscore $(r=0.46, p<0.01)$, local community score $(r=0.40, p<0.05)$, and society score $(r=0.39$, $p<0.05)$. This finding implies that larger organizations tend to recognize the importance of affective management and/or actually take into account stakeholders' affects when they made management decisions. This result supports the sixth hypothesis.

Table 7. Pearson's correlation coefficients between affectiveness scores and management performance indices related to investors' perspective (PER, PBR, net profit margin)

\begin{tabular}{cccccccc}
\hline & & \multicolumn{3}{c}{ Affectiveness score } & \multicolumn{4}{c}{ Sub score } \\
& & Winning & Average & Employee & Customer & $\begin{array}{c}\text { Local } \\
\text { community }\end{array}$ & Society \\
\hline \multirow{2}{*}{ PER } & $r$ & $\mathbf{0 . 3 2}^{+}$ & $\mathbf{0 . 3 1}^{+}$ & 0.11 & $\mathbf{0 . 3 6 ^ { * }}$ & 0.07 & 0.22 \\
& $n$ & 32 & 33 & 32 & 31 & 31 & 31 \\
PBR & $r$ & $\mathbf{0 . 3 0}^{+}$ & $\mathbf{0 . 3 1}^{+}$ & $\mathbf{0 . 2 9}^{+}$ & $\mathbf{0 . 3 8 ^ { * }}$ & 0.20 & $\mathbf{0 . 3 5}^{*}$ \\
& $n$ & 36 & 36 & 36 & 35 & 35 & 35 \\
Net & $r$ & 0.11 & 0.16 & $\mathbf{0 . 2 8 ^ { + }}$ & 0.01 & 0.05 & 0.10 \\
profit & $n$ & 40 & 40 & 40 & 39 & 39 & 39 \\
\hline
\end{tabular}

Note. $+p<0.10, * p<0.05$.

Table 8. Pearson's correlation coefficients between affectiveness scores and size of the organization

\begin{tabular}{|c|c|c|c|c|c|c|c|}
\hline & & \multicolumn{2}{|c|}{ Affectiveness score } & \multicolumn{4}{|c|}{ Sub-score } \\
\hline & & Winning & Average & Employee & Customer & $\begin{array}{c}\text { Local } \\
\text { community }\end{array}$ & Society \\
\hline \multirow{2}{*}{ Size } & $r$ & $0.40^{*}$ & $0.42^{*}$ & 0.20 & $0.46^{*}$ & $0.40^{*}$ & $0.39^{*}$ \\
\hline & $n$ & 34 & 34 & 34 & 33 & 33 & 22 \\
\hline
\end{tabular}

Note. ${ }^{*} p<0.05$. 


\section{Difference between B2B and B2C businesses}

Organizations that engage in business with consumers (B2C) may be more sensitive to their influences on customers' and other stakeholders' affects than those doing business with other businesses (B2B). The affectiveness of management may have a greater impact on stakeholders of B2C than B2B businesses. Thus, the relationship between affectiveness scores and management performance indices might be different between B2B and B2C businesses. To investigate these possible differences, we further divided the responses into $\mathrm{B} 2 \mathrm{~B}$ and $\mathrm{B} 2 \mathrm{C}$ groups and then compared them.

Table 9 summarizes the means and standard deviations of affectiveness scores and management performance indices by the business categories of B2B and B2C groups, as well as the results of $t$-tests between business categories. B2C businesses had higher affectiveness scores than B2B businesses: winning score $(t=-2.04, p<0.05)$, average score $(t=-2.01, p<0.10)$, local community sub-score $(t=-2.55, p<0.05)$, and society sub-score $(t=-2.79, p<0.01)$. Furthermore, B2C businesses also showed higher management performance with ROA $(t=-1.75, p<0.10)$ and significantly higher net profit margin $(t=-2.28, p<0.05)$ than B2B businesses.

Table 9. Means, standard deviations, and t-test results of affectiveness scores and management performance indices by B2B and B2C businesses

\begin{tabular}{|c|c|c|c|c|c|c|}
\hline & & $\begin{array}{c}\text { Type of } \\
\text { business }\end{array}$ & $n$ & $M$ & $S D$ & $t$ \\
\hline \multirow{4}{*}{$\begin{array}{l}\text { Affectiveness } \\
\text { scores }\end{array}$} & \multirow{2}{*}{ Winning } & B2B & 23 & 0.90 & 0.54 & $-2.04^{*}$ \\
\hline & & B2C & 15 & 1.30 & 0.67 & \\
\hline & \multirow{2}{*}{ Average } & B2B & 23 & 69.80 & 9.25 & $-2.01^{+}$ \\
\hline & & $\mathrm{B} 2 \mathrm{C}$ & 15 & 77.11 & 13.24 & \\
\hline \multirow{8}{*}{ Sub-scores } & \multirow{2}{*}{ Employee } & B2B & 23 & 67.70 & 8.71 & -1.18 \\
\hline & & B2C & 15 & 71.68 & 12.16 & \\
\hline & \multirow{2}{*}{ Customer } & B2B & 23 & 74.23 & 10.40 & -0.88 \\
\hline & & B2C & 15 & 77.80 & 14.81 & \\
\hline & \multirow{2}{*}{ Local community } & B2B & 23 & 54.90 & 19.14 & $-2.55^{*}$ \\
\hline & & B2C & 15 & 70.83 & 18.42 & \\
\hline & \multirow{2}{*}{ Society } & B2B & 23 & 57.40 & 14.60 & $-2.79^{* *}$ \\
\hline & & $\mathrm{B} 2 \mathrm{C}$ & 15 & 72.75 & 19.44 & \\
\hline \multirow{10}{*}{$\begin{array}{l}\text { Performance } \\
\text { indices }\end{array}$} & \multirow{2}{*}{ ROA } & B2B & 20 & 8.09 & 10.59 & $-1.75^{+}$ \\
\hline & & B2C & 15 & 14.45 & 10.72 & \\
\hline & \multirow{2}{*}{ ROE } & B2B & 18 & 6.65 & 25.35 & -1.43 \\
\hline & & B2C & 15 & 16.74 & 11.38 & \\
\hline & \multirow{2}{*}{ PER } & B2B & 14 & 15.70 & 9.82 & -0.23 \\
\hline & & B2C & 14 & 16.88 & 17.27 & \\
\hline & \multirow{2}{*}{ PBR } & B2B & 17 & 1.62 & 0.79 & -1.36 \\
\hline & & B2C & 15 & 2.44 & 2.32 & \\
\hline & \multirow{2}{*}{ Net profit } & $\mathrm{B} 2 \mathrm{~B}$ & 20 & -2.09 & 27.25 & $-2.28^{*}$ \\
\hline & & B2C & 15 & 14.89 & 10.81 & \\
\hline
\end{tabular}

Note. $+p<0.10, * p<0.05,{ }^{* *} p<0.01$. 
Tables 10 and 11 show the results of a correlation analysis between affectiveness scores and financial performance indices by business categories (B2B and B2C). Table 10 shows correlations between overall affectiveness scores (winning and average scores) and performance indices, while Table 11 shows correlations between stakeholder subscores and performance indices.

In Table 10, though not statistically significant, B2C responses showed some positive correlations between affectiveness scores and PER and PBR, while B2C responses did not. This issue is addressed later in the discussion section.

In Table 11, B2C responses showed a moderate positive correlation between employee sub-score and PER $(r=0.47, p<0.10)$. In addition, although not statistically significant, B2C responses showed some positive correlations between customer sub-score and management performance indices (PER and PBR). This point will be addressed further in the discussion section.

Table 10. Pearson's correlation coefficients between affectiveness scores (winning score and average score) and management performance indices

\begin{tabular}{cccccc}
\hline & \multicolumn{5}{c}{ Affectiveness score } \\
& & B2B & B2C & B2B & B2C \\
\hline \multirow{2}{*}{ ROA } & $r$ & 0.14 & 0.01 & -0.01 & -0.07 \\
& $n$ & 20 & 15 & 20 & 15 \\
ROE & $r$ & 0.21 & -0.13 & 0.01 & -0.24 \\
& $n$ & 18 & 15 & 18 & 15 \\
PER & $r$ & -0.05 & $\mathbf{0 . 4 0}$ & 0.14 & $\mathbf{0 . 3 6}$ \\
& $n$ & 14 & 14 & 14 & 14 \\
PBR & $r$ & 0.23 & $\mathbf{0 . 3 7}$ & 0.19 & $\mathbf{0 . 2 7}$ \\
& $n$ & 17 & 15 & 17 & 15 \\
Net & $r$ & -0.01 & -0.18 & 0.01 & -0.08 \\
profit & $n$ & 20 & 15 & 20 & 15 \\
\hline
\end{tabular}

Table 11. Pearson's correlation coefficients between stakeholder sub-scores and management performance indices

\begin{tabular}{|c|c|c|c|c|c|c|c|c|c|}
\hline & & \multicolumn{8}{|c|}{ Sub-score } \\
\hline & & \multicolumn{2}{|c|}{ Employee } & \multicolumn{2}{|c|}{ Customer } & \multicolumn{2}{|c|}{ Local community } & \multicolumn{2}{|c|}{ Society } \\
\hline & & B2B & B2C & B2B & B2C & B2B & B2C & B2B & B2C \\
\hline \multirow{2}{*}{ ROA } & $r$ & 0.28 & 0.07 & -0.19 & 0.01 & -0.07 & -0.09 & -0.09 & -0.14 \\
\hline & $n$ & 20 & 15 & 20 & 15 & 20 & 15 & 20 & 15 \\
\hline \multirow{2}{*}{ ROE } & $r$ & 0.08 & -0.13 & -0.20 & -0.18 & 0.02 & -0.18 & 0.21 & -0.23 \\
\hline & $n$ & 18 & 15 & 18 & 15 & 18 & 15 & 18 & 15 \\
\hline \multirow{2}{*}{ PER } & $r$ & 0.20 & $0.47+$ & 0.22 & 0.36 & -0.02 & 0.13 & 0.11 & 0.17 \\
\hline & $n$ & 14 & 14 & 14 & 14 & 14 & 14 & 14 & 14 \\
\hline \multirow{2}{*}{ PBR } & $r$ & 0.22 & 0.26 & 0.04 & 0.38 & 0.13 & 0.14 & 0.22 & 0.25 \\
\hline & $n$ & 17 & 15 & 17 & 15 & 17 & 15 & 17 & 15 \\
\hline \multirow{2}{*}{$\begin{array}{l}\text { Net } \\
\text { profit }\end{array}$} & $r$ & 0.33 & 0.01 & -0.16 & -0.08 & -0.19 & -0.06 & -0.18 & -0.13 \\
\hline & $n$ & 20 & 15 & 20 & 15 & 20 & 15 & 20 & 15 \\
\hline
\end{tabular}




\section{Discussion}

This study investigated the relationship between the affectiveness of management and the management performance of organizations. The overall results suggest that if the top management of an organization considers the affective experiences of stakeholders (such as customers, employees, local community and society), then the performance of the organization appears to be better. These results support the underlying purpose of this study, i.e., to study the importance of the concept of affectiveness in management.

Scores that represented the overall affectiveness of the organization, i.e., winning score and average score, did not show statistically significant correlations with earnings indices such as ROA and ROE (Table 6), but these scores were significantly correlated with PER and PBR (Table 7). This finding implies that while the affective management concept might not have an instant impact on earnings, organizations that practice affective management are more likely to be appreciated by investors in the market. It might also be possible for a linkage between practices of affective management and performance to develop over the long term, and thus the relationship between them should be studied on the basis of a time series considering possible time delays.

It is also noteworthy that affectiveness scores (except for the employee sub-score) showed significant correlations with the size of organizations (Table 8). The larger the organization is, the more likely it is that its management recognizes the importance of considering the affective experiences of stakeholders and/or actually practices affective management. One possible reason for this could be that larger organizations often have more stakeholders than smaller ones, and thus they are required to take into consideration the influences of management decisions on stakeholders' affective experiences. Another possible reason might be that the larger organizations have a greater capacity than smaller ones to take account of stakeholders' affects in management decisions.

\section{Customers}

In terms of affectiveness scores by stakeholder categories, the positive correlations between customer sub-scores and management performance were intuitive. The results for PER and PBR showed statistically significant correlations (Table 7) while those for ROA and ROE did not (Table 6), suggesting that taking care of customers' affective experiences might have a greater direct influence on market appreciation than on instant profitability.

It is also understandable, although not statistically significant, that B2C businesses had higher correlations between financial performances (PER and PBR) and customer sub-scores than B2B businesses (Table 11). One possible explanation for the nonsignificant correlations could be the small number of organizations in this study. However, Table 9 illustrates that while both B2C and B2B businesses have their highest stakeholder sub-scores in the customer category, the B2C businesses showed a higher average customer sub-score than the B2B businesses. This result suggests that top 
managers of B2C businesses are paying more attention and making efforts to take customers' affects into their management decision-making.

\section{Employees}

Employee sub-scores were also found to have moderate positive correlations with ROA, PBR, and net profit margin. Research has already shown that employees' positive affective experiences in the workplace lead to the development of positive behaviors such as action and cognition (Fredickson, 2003), work engagement (Stairs and Galpin, 2010), motivation (Fisher, 2010), increased productivity (Fredickson, 2003), and willingness to work overtime (Truss et al., 2006). Employees' positive experiences are known to lead to better financial performance for the organization, improve the discretionary efforts of employees (Corporate Leadership Council, 2004), raise target sales goals (Wellings, Bernthal, and Phelps, 2005), and drive more profit (Harter et al., 2002, 2010) and better earnings per share (ISR, 2006). In addition, employees' positive attitudes towards the workplace are known to lead to improved organizational performance (Fulmer, Gerhart, and Scott, 2003; Ballou, Godwin, and Shortridge, 2003). While there are a number approaches for organizations to improve the positive experiences of employees, including bottom-up approaches and making it the responsibility of middle managers, this study has emphasized the importance of the commitment of top managers to the affects of employees. The results show that the greater the extent that top management takes into account employees' affective experiences in their management decision-making, the better the performance of the organization.

\section{Local community and society}

In this study, using samples from Thailand, the local community sub-scores showed no significant correlations with performance indices, while society sub-scores showed overall positive correlations. It might be possible that the top managers who participated in this study did not pay much attention to the affective experiences of the local community. This finding is also suggested by the results that showed that the local community sub-scores were the lowest amongst stakeholder sub-scores, for both B2B and B2C businesses (Table 9). It might be expected that top management would care less about their local community than society in general because, for example, of their small population when compared with the entire country. The limited impact of the local community, in turn, may result in relatively small or delayed impacts on the management performance of the organizations, for example in terms of profitability or market valuations-valuations by local community populations may be dominated by those of the larger society, if these are indeed different.

Another possibility is the cultural background. The respondents in this study were all from Thailand. It might be possible that awareness among top management of the importance of considering stakeholders' affective experiences, especially of those other than customers and employees, has not yet matured in this country. 
Evidence from European companies shows a positive relationship between financial performance and supporting local community activities (Bird et al., 2007). To address this cultural difference, international comparative studies with broader samples should be pursued in future research. It might also be interesting to investigate how the attitudes of the respondents in this study may change in the future.

Commitment to society has positive influences on financial performance (Branco and Rodrigues, 2006; McWilliam and Siegel, 2000). Branco and Rodrigues (2006) showed that CSR activities bring sustainability to the financial performances of organizations. While the results of this study accord with previous studies, this study also emphasized the importance that top managers themselves should be aware and actually commit to the affective experiences of society to improve organizational performance.

\section{Conclusion}

This study represented preliminary results regarding the relationship between awareness and practice of affective management and management performance of organizations. The overall results showed that affectiveness indices were positively correlated with performance indices, suggesting that those affectiveness indices could be good predictors of organizational performance. The results also suggest that the further promotion of the affective management concept might lead to a better appreciation by stakeholders and the market, and thus result in better management performance, i.e., growth, profitability, and the sustainability of organizations.

The limitations of this study include the following issues. First, the sample organizations are only from Thailand. Although it seems logical that a study from other cultures would reveal a similar pattern to this study, to uncover possible differences across cultures, international comparative studies with samples from a range of countries should be pursued because top management from different countries may behave differently.

Second, the performance indices employed in this study were only from one fiscal year (2010). To eliminate any possible economic anomalies in a particular year, and to analyze the long-term relations between affectiveness indices and management performance as discussed, management indices and financial data from more than one year should be used for analysis.

Third, the stakeholders in this study were limited to customers, employees, local communities, and society in general. Other categories of stakeholders, such as shareholders or business partners, may impact on organizational performance through their affective experiences. The analysis of these categories should also be included in future studies.

Fourth, as the personality of individuals relates with actions, desires, feelings, and thoughts, it is expected that the affectivity personality of top managements might result in difference in their effectiveness and attitude towards affective management. Thus, the differences in the affectivity personality of top management might be further studied in relation to their affective management practices and performances. 
Finally, although this study showed evidence of correlations between affective indices and management performance indices, the mechanisms that connect them are not yet clear. Possible causal relationships should be further explored and validated with greater numbers of respondents in future studies.

\section{References}

Amsa, P. (1991). Influencing managers' affective world: Role of behavioural science training. Economic and Political Weekly, 26(48), 129-130.

Authayarat, W., Umemuro, H., Murata, K., and Jiamsanguanwong, A. (2011, June). Development of affective management concept and scorecard. Paper presented at the International Conference on Business, Engineering, and Industrial Applications, Kuala Lumpur. Abstract retrieved from http://ieeexplore.ieee.org/xpls/abs_all. jsp?arnumber $=5994226$ andtag $=1$

Babkus, E., Bienstock, C. C., and Van Scotter, J. R. (2004). Linking perceived quality and customer satisfaction to store traffic and revenue growth. Decision Sciences, 35(4), 713-737.

Bahn, S., Lee, C., Nam, C. S., and Yun, M. H. (2009). Incorporating affective customer needs for luxuriousness into product design attributes. Human Factors Ergonomics Manufacturing, 19(2), 105-127. doi:10.1002hfm.20140.

Ballou, B., Godwin, N. H., and Shortridge, R. T. (2003). Firm value and employee attitudes on workplace quality. Accounting Horizons, 17(4), 329-341.

Bird, R., Hall, A. D., Momentè, F., and Reggiani, F. (2007). What corporate social responsibility activities are valued by the market? Journal of Business Ethics, 76, 189-206. doi:10.1007/s10551-006-9268-1.

Branco, M. C. and Rodrigues, L. L. (2006). Corporate social responsibility and resourcebased perspectives. Journal of Business Ethics, 69, 111-132. doi:10.1007/s10551006-9071-z.

Broeck, V. D. (2009). Factors influencing uptake of corporate social responsibility. Retrieved from European Working Conditions Observatory website: http://www.eurofound.europa.eu/ewco/2009/05/LU0905019I.htm.

Cambell, D., Shrives, P., and Bohmbach-saager, H. (2001). Voluntary disclosure of mission statements in corporate annual reports: Signals what and to whom? Business and Society Review, 106(1), 65-87.

Carroll, A. B. and Näsi, J. (1997). Understanding stakeholder thinking: Themes from a Finnish conference. Business Ethics: A European Review, 6(1), 46-51. doi:10.1111/1467-8608.00047.

Corporate Leadership Council (2004). Driving performance and retention through employee engagement: A quantitative analysis of effective engagement strategies. Retrieved from McKenzie Consulting website: http://www.mckpeople.com.au/SiteMedia/w3svc161/Uploads/Documents/ 760af459-93b3-43c7-b52a-2a74e984c1a0.pdf. 
Devaraj, S., Matta, K. F., and Conlon, E. (2001). Product and service quality: The antecedents of customer loyalty in the automotive industry. Production and Operations Management, 10(4), 424-439.

Erez, A. and Isen, A. M. (2002). The influence of positive affect on the components of expectancy motivation. Journal of Applied Psychology, 87, 1055-1067.

Fisher, C. D. (2003). Why do lay people believe that satisfaction and performance are correlated? Possible sources of a commonsense theory. Journal of Organizational Behavior, 24, 753-777.

Fisher, C. D. (2010). Happiness at work. International Journal of Management Reviews, 12, 384-412. doi:10.1111/j.1468-2370.2009.00270.x.

Fredrickson, B. L. (2003). Positive emotions and Upward Spirals In Organizations. In K.S. Cameron, J. E. Dutton, R. E. Quinn (Eds), Positive organizational scholarship (pp. 163175). San Francisco, CA: Berrett-Koehler.

Fulmer, I., Gerhart, B., and Scott, K. (2003). Are the 100 best better? An empirical investigation of the relationship between being a 'great place to work' and firm performance. Personnel Psychology, 56, 595-993.

George, J. M. and Brief, A. P. (1996). Motivational agendas in the workplace: The effects of feelings on focus of attention and work motivation. Research in Organizational Behavior, 18, 75-109.

Harrison, D. A., Newman, D. A., and Roth, P. L. (2006). How important are job attitudes? Meta-analytic comparisons of integrative behavioral outcomes and time sequences. Academy of Management Journal, 49, 305-325.

Harter, J. K., Schmidt, F. L., and Hayes, T. L. (2002). Business-unit-level relationship between employee satisfaction, employee engagement, and business outcomes: A meta-analysis. Journal of Applied Psychology, 87(2), 268-279.

Harter, J. K. and Blacksmith, N. (2010). Employee engagement and the psychology of joining, staying in, and leaving organization. In P. A. Linley, S. Harrington, and N. Garcea (Eds.), Oxford Handbook of Positive Psychology and Work (pp. 121-130). New York, NY: Oxford University Press.

Hodges, T. D. and Asplund, J. (2010). Strengths development. In P. A. Linley, S. Harrington, and N. Garcea (Eds.), Oxford Handbook of Positive Psychology and Work (pp.213220). New York, NY: Oxford University Press.

llies, R. and Judge, T. A. (2002). Understanding the dynamic relationships among personality, mood, and job satisfaction: A field experience sampling study. Organizational Behavior and Human Decision Processes, 89, 1119-1139.

ISR. (2006, June 29). Engaged employees help boost the bottom line. Retrieved from PRWEB website: http://www.prweb.com/re;eases/2006/6/prweb405040.htm.

Larson, R. (2009). The Future of Customer Relationship Management. Retrieved from Liberty University, Faculty Publications and Presentations, Paper 7: Retrieved from http://difitalcommons.liberty.edu/busi_fac_pubs/7.

Lewis, B. R. and Soureli, M. (2006). The antecedents of consumer loyalty in retail banking. Journal Consumer Behavior, 5, 15-31. doi:10.1002/cb.46. 
Locke, K. (1996). A funny thing happened! The management of consumer emotions in service encounters. Organization Science, 7(1), 40-59. doi:10.1287/orsc.7.1.40.

Lyubomirsky, S., King, L., and Diener, E. (2005). The benefits of frequent positive affect: Does happiness lead to success? Psychological Bulletin, 131, 803-855.

McWilliams, A. and Siegel, D. (2000). Corporate social responsibility and financial performance: Correlation or misspecification? Strategic Management Journal, 21, 603-609.

Millard, N. (2006). Learning from the 'wow' factor - How to engage customers through the design of effective affective customer experiences. BT Tech Journal, 24(1), 1116. doi: 10.1007/s10550-006-0016-y.

Nagamachi, M. (2008). Perspectives and new trend of Kansei/Affective engineering. The TQM Journal, 20(4), 290-298. doi:10.1108/17542730810881285.

Nayyar, P. R. (1995). Stock market reactions to customer service changes. Strategic Management Journal, 16, 39-53. doi:10.1002/smj.4250160106.

Norman, D. A. (2004). Emotional design: Why we love (or hate) everyday things. New York: Basic books.

Parasuraman, A., Zeihaml, V.A., and Berry, L. L. (1988). SERVQUAL: A multiple-item scale for measuring consumer perceptions of service quality. Journal of Retailing, 64(1), 22-40.

Reinartz, W. J. and Kumar, V. (2003). The impact of customer relationship characteristics on profitable lifetime duration. The Journal of marketing, 67(1), 77-99.

Stairs, M. and Galpin, M. (2010). Positive engagement: From employee engagement to workplace happiness. In P. A. Linley, S. Harrington, and N. Garcea (Eds.), Oxford Handbook of Positive Psychology and Work (pp. 155-174). New York, NY: Oxford University Press.

Staw, B. M., and Barsade, S. G. (1993). Affect and Managerial Performance: A test of the sadder-but-wiser vs. happier-and-smarter hypotheses. Administrative Science Quarterly, 38, 304-331.

Strong, K. C., Ringer, R. C., and Taylor, S. A. (2001). The rules of stakeholder satisfaction (timeliness, honesty, empathy). Journal of Business Ethics, 32, 219-230. doi:10.1023/A:1010714703936.

Tang, Q. and Umemuro, H. (2012). Factors that elicit human affects: Affective responses among Japanese adults. Journal of Japan Industrial Management Association, 62(6), 311-322.

Truss, C., Soane, E., Edwards, C., Wisdom, K., Croll, A., and Burnett, J. (2006). Working life: Employee attitudes and engagement 2006. London: Chartered Institute of Personnel and Development.

Umemuro, H. (2009). Affective technology, affective management, towards affective society. In J.A. Jacko. (Ed.), Lecture Notes in Computer Science: Vol. 5612/2009. Human-Computer Interaction. Ambient, Ubiquitous and Intelligent Interaction (pp. 683-692). doi:10.1007/978-3-642-02580-8_75. 
Umemuro, H. (2011). Affective technology through affective management. In C. Stephanidis (Ed.), Lecture Notes in Computer Science: Vol. 6766/2011. Universal Access in Human-Computer Interaction. User Diversity (pp. 513-518). doi:10.1007/978-3-642-21663-3_55.

Wellings, R. S., Bernthal, P., and Phelps, M. (2005). Employee engagement: The key to realizing competitive advantage. Retrieved from DDI World Development Dimensions International website: http://www.ddiworld.com/DDIWorld/media/ monographs/employeeengagement_mg_ddi.pdf?ext=.pdf.

Whitehouse, L. (2006). Corporate social responsibility: Views from the frontline. Journal of Business Ethics, 63, 279-296.

Zelenski, J. M., Murphy, S. A., and Jenkins, D. A. (2008). The happy-productive worker thesis revisited. Journal of Happiness Studies, 9(4), 521-537. doi:10.1007/s10902008-9087-4.

\section{Abstract (in Polish)}

Zarzqdzanie afektywne (ang. affective management) jest nowq koncepcjq zarzq̨dzania zgodnie z którq procesy decyzyjne menedżerów powinny brać pod uwagę doświadczenia emocjonalne zainteresowanych stron. Aby wykazać, że ta koncepcja może miećpozytywny wpływ na funkcjonowanie organizacji, autorzy pracy podejmujq badanie relacji zachodzqcej pomiędzy afektywnościq kierownictwa firmy i wskaźnikami funkcjonowania organizacji. Autorzy proponujq ankietę, opartq o Kartę Afektywnego Zarzqdzania, dla zbadania postrzegania ważności afektywnego zarządzania i stosowanych praktyk afektywnego zarzq̨dzania wśród menedżerów. Badanie zostało przeprowadzone na próbie 43 członków ścisłego kierownictwa firm w Tajlandii. Rezultaty analizy korelacji pomiędzy wskaźnikami afektywnego zarzq̨dzania i kluczowymi wskaźnikami rentowności firmy wskazujq na istnienie pozytywnego zwiqzzeku pomiędzy praktykowaniem zarzq̨dzania afektywnego i rezultatami firm w zakresie ich rentowności oraz ich wartości rynkowej.

Słowa kluczowe: zarzadzanie afektywne, interesariusze, zarzqdzanie, wpływ, emocje, uczucia. 